\title{
THE IMPACT OF MICROFINANCE INSTITUTIONS (MFI) ON SMALL AND MEDIUM ENTERPRISES (SME) IN KOSOVO
}

\author{
Njomëza Tasha ${ }^{1}$ \\ Luan Vardari $^{2}$ \\ Dena Arapi ${ }^{3}$
}

\begin{abstract}
Small and medium enterprises are the key factors in the economy of a country. Their good development means that there are bigger chances of employment and economic development of a country. In the other side microfinance institutions offer services like loan and lecture programs to the individuals and businesses with lower incomes and for those rural. Small and medium enterprises are interconnected with microfinance institutions since the latest provide a great financial help to these businesses, the opportunity to meet their debts and other obligations. We have to consider that the main goal of microfinance institutions is to help small and medium businesses.
\end{abstract}

Then, we have to emphasize that the main goal of this work is:

- The review and presentation of the importance of small and medium enterprises;

- The impact of microfinance institutions on SME's;

- Reasons and purposes of microfinance institutions help.

Our survey is based on the literature, publications and articles. Also, we are going to do questionnaires for small and medium businesses. In this survey, we are going to use analytical and descriptive methods. As a conclusion, we can conclude that the microfinance institutions have a great impact on small and medium enterprises. Keywords: Enterprise, Innovation, Microfinance, Institution

\footnotetext{
${ }^{1}$ KosInvest, njomza_beqiri_@hotmail.com

${ }^{2}$ University of Prizren “UKSHIN HOTI”, Faculty of Economics, luan.vardari@uni-prizren.com

${ }^{3}$ University of Prishtina, Faculty of Law, denaarapi@ @otmail.com
} 


\section{SMALL AND MEDIUM ENTERPRISES}

Small and medium enterprises represent $99 \%$ of businesses in Europe in general, and in Balkans in particular. Defining small and medium enterprises varies from annual turnover, number of employees and values of assets. Based on this we can get this overview:

\begin{tabular}{|l|l|l|l|}
\hline $\begin{array}{l}\text { Company } \\
\text { Category }\end{array}$ & $\begin{array}{l}\text { Number of } \\
\text { Employees }\end{array}$ & Annual turnover & \multicolumn{1}{c|}{ Gross assets } \\
\hline Medium & $\begin{array}{l}<10 \text { employees up } \\
\text { to }>50 \text { employees }\end{array}$ & $<2 \mathrm{~m} €$ up to $>4 \mathrm{~m} €$ & $<1 \mathrm{~m} €$ up to $>2 \mathrm{~m} €$ \\
\hline Small & $\begin{array}{l}\text { Up to10 employ- } \\
\text { ees }\end{array}$ & $\begin{array}{l}<50 \text { thousand } € \text { up to }>2 \\
\mathrm{~m} €\end{array}$ & $\begin{array}{l}<25 \text { thousand } € \text { up to } \\
1 \mathrm{~m} €\end{array}$ \\
\hline Micro & $\begin{array}{l}\text { Less than } 10 \mathrm{em}- \\
\text { ployees }\end{array}$ & Less than 50 thousand $€$ & $\begin{array}{l}\text { Less than } 25 \text { thousand } \\
€\end{array}$ \\
\hline
\end{tabular}

Figure 1. Determining criteria of business category

It is worth mentioning that the small and medium businesses should not be part of the leading companies in the country that are operating, as well as they have to be independent. They are characterized by making decisions easier, centralization, way of governance from top to bottom, numerous innovations etc. Establishment of those enterprises started, based on the needs to create e more workplaces. Small and medium enterprises have the possibility to build activities as well as abilities for initiatives and different ambitions.

Based on the OECD's report, has been ascertained that around 60-70\% of developed countries in the world are businesses of this type. Small and medium businesses in general play an important role in the economy of developed countries and those under development, comprising $40-80 \%$ of businesses in the manufacturing sector. 


\begin{tabular}{|c|c|c|c|c|c|c|c|c|c|}
\hline & \multirow[b]{2}{*}{ Year } & \multicolumn{4}{|c|}{$\begin{array}{l}\text { Number of enterprises/establishments } \\
\text { of which in employment size class }\end{array}$} & \multicolumn{4}{|c|}{$\begin{array}{c}\text { Employment } \\
\text { of which in employment size class }\end{array}$} \\
\hline & & $1-19$ & $20-99$ & $100-499$ & $500+$ & $1-19$ & $20-99$ & $100-499$ & $500+$ \\
\hline United States & 1993 & 73.7 & 19.8 & 5.1 & 1.4 & 7.4 & 14.6 & 16.5 & 61.5 \\
\hline Canada & 1994 & 50.6 & 37.8 & 10.2 & 1.4 & 7.6 & 27.8 & 39.4 & 25.2 \\
\hline Mexico & 1994 & 80.3 & 15.1 & 2.7 & 2.0 & 12.2 & 21.2 & 15.6 & 51 \\
\hline Australia & 1994 & 82.0 & 14.1 & 3.4 & 0.4 & 22.3 & 27.5 & 32.7 & 17.5 \\
\hline New Zealand & 1994 & 90.6 & 7.7 & 1.5 & 0.3 & 27.3 & 24.7 & 24.0 & 24.0 \\
\hline Austria & 1993 & 43.2 & 41.5 & 10.0 & 5.2 & 4.3 & 26.9 & 23.4 & 45.5 \\
\hline Belgium & 1993 & 80.4 & 15.3 & 3.7 & 0.6 &.. & .. & .. & .. \\
\hline Denmark & 1993 & 82.0 & 14.6 & 3.1 & 0.3 & .. & .. & .. & .. \\
\hline Finland & 1992 & 50.8 & 36.1 & 11.6 & 1.5 & .. & .. & .. & .. \\
\hline Italy & 1992 & 89.7 & 9.0 & 1.2 & 0.2 & 38.7 & 25.0 & 17.3 & 19.0 \\
\hline Luxembourg & 1992 & 79.4 & 15.0 & 4.7 & 0.9 & 13.0 & 22.1 & 35.0 & 29.9 \\
\hline Netherlands & 1993 & 78.0 & 17.2 & 4.3 & 0.6 & 15.7 & 24.8 & 27.8 & 31.7 \\
\hline Norway & 1994 & 40.2 & 47.4 & 7.5 & 4.9 & 9.3 & 34.9 & 18.2 & 37.6 \\
\hline Portugal & 1994 & 85.8 & 11.8 & 2.2 & 0.2 & 23.5 & 32.3 & 27.8 & 16.5 \\
\hline Sweden & 1993 & 44.4 & 40.8 & 12.4 & 2.4 & 6.9 & 23.1 & 35.3 & 34.7 \\
\hline Switzerland & 1991 & 84.2 & 12.3 & 3.1 & 0.4 & 20.2 & 26.9 & 31.3 & 21.5 \\
\hline Czech Republic & 1995 & 94.9 & 2.9 & 1.6 & 0.5 & 18.0 & 10.3 & 24.6 & 47.1 \\
\hline Turkey & 1992 & 36.6 & 47.1 & 13.3 & 3.0 & 5.5 & 22.2 & 32.2 & 40.1 \\
\hline United Kingdom & 1994 & 82.7 & 12.9 & 3.7 & 0.8 & 13.2 & 21.6 & 28.9 & 36.3 \\
\hline
\end{tabular}

Fig. 2 Number of the enterprises in the manufacturing sector ${ }^{4}$

While this establishment trend of small and medium enterprises has started to decrease, on the other hand, the manufacturing sector of construction has started to develop over the years. Around 80-90\% of the workers are focused on the construction sector. The variables of the employees based on the sectors are presented in the picture bellow. It is worth mentioning that small and medium enterprises are led by the textile sector, restaurants and hotels.

Small and medium enterprises in Kosovo, are considered very important since our country is in transition and with a high unemployment rate, where those businesses enable the mitigation of unemployment. These businesses are mainly entrepreneur businesses from the rural places or self-employed women that work for survival.

\footnotetext{
${ }^{4}$ OECD, Small Businesses, Job Creation and Groëth: Facts, Obstacles and Best Practices, Istanbul,2016
} 


\begin{tabular}{|c|c|c|c|c|c|c|c|}
\hline & \multirow[t]{3}{*}{ Year } & \multicolumn{6}{|c|}{ Employment size class } \\
\hline & & $1-9$ & $10-19$ & $20-99$ & $100-499$ & $500+$ & Total \\
\hline & & \multicolumn{6}{|c|}{ Percentages } \\
\hline \multicolumn{8}{|l|}{ United States } \\
\hline \multirow[t]{2}{*}{ Manufacturing } & 1993 & 3.5 & 3.9 & 14.6 & 16.5 & 61.5 & 100.0 \\
\hline & 1988 & 3.1 & 3.7 & 14.5 & 16.1 & 62.6 & 100.0 \\
\hline \multirow[t]{2}{*}{ Construction } & 1993 & 28.6 & 17.0 & 30.7 & 12.5 & 11.1 & 100.0 \\
\hline & 1988 & 25.5 & 16.5 & 31.7 & 14.8 & 11.5 & 100.0 \\
\hline \multirow{2}{*}{$\begin{array}{l}\text { Wholesale and retail trade, } \\
\text { hotels and restaurants }\end{array}$} & 1993 & 13.1 & 9.9 & 22.2 & 11.8 & 43.0 & 100.0 \\
\hline & 1988 & 13.6 & 10.4 & 23.2 & 11.9 & 40.8 & 100.0 \\
\hline \multirow[t]{2}{*}{ Finance, insurance and real estate } & 1993 & 12.5 & 5.5 & 13.8 & 12.2 & 56.1 & 100.0 \\
\hline & 1988 & 12.3 & 5.7 & 14.3 & 12.4 & 55.3 & 100.0 \\
\hline \multirow[t]{2}{*}{ Total non-farm business sector } & 1993 & 10.7 & 7.7 & 18.8 & 13.1 & 49.6 & 100.0 \\
\hline & 1988 & 10.5 & 7.8 & 19.3 & 13.3 & 49.0 & 100.0 \\
\hline \multicolumn{8}{|l|}{ Canada } \\
\hline \multirow[t]{2}{*}{ Manufacturing } & $1992 \ldots$ & & 11.4 & 20.3 & 22.0 & 46.3 & 100.0 \\
\hline & $1989 \ldots$ & & 9.9 & 21.3 & 22.8 & 46.0 & 100.0 \\
\hline \multirow[t]{2}{*}{ Construction } & $1992 \ldots$ & & 56.0 & 26.7 & 12.3 & 5.0 & 100.0 \\
\hline & $1989 \ldots$ & & 51.0 & 29.4 & 14.5 & 5.1 & 100.0 \\
\hline \multirow{2}{*}{$\begin{array}{l}\text { Wholesale and retail trade, } \\
\text { hotels and restaurants }\end{array}$} & $1992 \ldots$ & & 33.6 & 25.7 & 13.2 & 27.5 & 100.0 \\
\hline & $1989 \ldots$ & & 28.9 & 24.5 & 12.9 & 33.7 & 100.0 \\
\hline \multirow[t]{2}{*}{ Finance, insurance and real estate } & $1992 \ldots$ & & 17.8 & 12.1 & 9.7 & 60.4 & 100.0 \\
\hline & $1989 \ldots$ & & 17.2 & 14.4 & 10.8 & 57.6 & 100.0 \\
\hline \multirow[t]{2}{*}{ Total non-farm business sector } & $1992 \ldots$ & & 25.5 & 20.8 & 15.1 & 38.6 & 100.0 \\
\hline & $1989 \ldots$ & & 23.5 & 22.0 & 16.3 & 38.2 & 100.0 \\
\hline \multicolumn{8}{|l|}{ Japan } \\
\hline \multirow[t]{2}{*}{ Manufacturing } & 1993 & 12.5 & 10.4 & 30.8 & 24.6 & 21.7 & 100.0 \\
\hline & 1986 & 13.7 & 11.0 & 30.6 & 23.5 & 21.3 & 100.0 \\
\hline \multicolumn{8}{|l|}{ France } \\
\hline \multirow[t]{2}{*}{ Manufacturing } & 1992 & 8.1 & 5.0 & 22.4 & 23.6 & 40.9 & 100.0 \\
\hline & 1990 & 10.1 & 5.1 & 22.0 & 23.1 & 39.7 & 100.0 \\
\hline \multirow[t]{2}{*}{ Construction } & 1992 & 29.0 & 11.5 & 27.5 & 14.0 & 18.0 & 100.0 \\
\hline & 1990 & 33.9 & 10.8 & 26.7 & 12.8 & 15.8 & 100.0 \\
\hline \multirow{2}{*}{$\begin{array}{l}\text { Wholesale and retail trade, } \\
\text { hotels and restaurants }\end{array}$} & 1992 & 32.9 & 10.3 & 25.8 & 12.4 & 18.5 & 100.0 \\
\hline & 1990 & 38.6 & 9.8 & 23.7 & 11.2 & 16.8 & 100.0 \\
\hline \multirow[t]{2}{*}{ Finance, insurance and real estate } & 1992 & 15.9 & 7.2 & 19.6 & 17.9 & 39.4 & 100.0 \\
\hline & 1990 & 19.7 & 7.4 & 18.9 & 17.4 & 36.6 & 100.0 \\
\hline \multirow[t]{2}{*}{ Total non-farm business sector } & 1992 & 18.2 & 7.1 & 21.7 & 17.1 & 35.9 & 100.0 \\
\hline & 1990 & 22.0 & 7.0 & 21.0 & 16.2 & 33.7 & 100.0 \\
\hline
\end{tabular}

Fig.3 Classification of sectors and allocation of small and medium businesses in different countries

Small and medium businesses are the target of support from the countries where they operate, in order to create new jobs and large number of benefits which come from these types of businesses. Methods for financing of small and medium businesses usually include: overdrafts, different borrowings, leasing's, bank loans etc. For example, small and medium businesses in Germany have more opportunities to take a debt or loan than having overdraft. Foreign currency loans are characteristic for small and medium businesses of the countries like Denmark, Italy and Portugal (OECD, 2016) 


\section{MICROFINANCE INSTITUTIONS}

Poverty is the main reason for measuring the country economy in transition. Microfinance institutions are those institutions which offer loan services, deposits and other services for physical and legal persons with lower incomes. Unlike banks, these institutions give smaller loans. Nowadays microfinance institutions are known as the main means of reducing poverty, which have an important role in filling the space of formal microfinance institutions and rural poor businesses.

The main source of microfinance institutions accepts funding from Banks and other financial institutions, and then they distribute them to poorest people. Microfinance Institutions are organizations that offer loans and other services for villagers, micro-entrepreneurs, poor families and entrepreneur- women. The purpose of these institutions should be:

- To improve the quality of life for the poorest people by offering them financial services.

- To be a financial institution with a clear vision for the development of the community.

- To understand and evaluate what softens poverty reduction factors.

- To enable self-employment for the underprivileged people.

- To use the funds in a rational manner etc.

Since, the number of unemployment in Kosovo is high with around $40 \%$ of active population, respectively families are with lower incomes. In 2002, in Kosovo was established The Association of Microfinance Institutions of Kosovo, where the members are also Microfinance Institutions of Kosovo. Currently in Kosovo are operating some microfinance institutions like:

\section{$>\mathrm{AFK}$}

$>$ KGMAMF

$>$ KosInvest

$>\mathrm{KRK}$

$>$ Kep Trust

$>$ Finca

$>$ Start etc. 
So, like in whole world also in Kosovo, microfinance institutions have the main purpose to mitigate the poverty and help the businesses with lower incomes.

\section{IMPACT OF FINANCIAL INSTITUTIONS ON SMALL AND MEDIUM BUSINESSES IN KOSOVO}

Small and medium enterprises in Kosovo, mainly have lower incomes. Their bigger barrier is debt recovery and initial capital. In order to have success, to be productive, competitive and to affect mitigation of unemployment, small and medium businesses should have financing so that they can achieve all this. Small and medium enterprises are almost unable to reap success without having any loan or financing. Therefore, the importance of these institutions comes into operation in this case.

In Kosovo as a story of success we can mention some microfinance institutions like:

Finca- is the organization with the Headquarter in Washington DC, USA, with its 21 branches in all continents that makes it one of the most important microfinance institutions in Kosovo. Finca offers loans and lecture programs with lots of its subbranches all over Kosovo.

KRK- offer loans for farmers, individuals and SME's. This institution for a short period of time has managed to open its sub-branches all over Kosovo, thus being a great contribution for villagers and its small and medium businesses.

Kep Trust-is considered as the most important and the biggest microfinance institution in Kosovo, offering lending and loans of a wide range of its products. It possesses around 31 sub-branches all around Kosovo territory.

Kosovo Government has established supportive policies for the small and medium enterprises. Through these policies, it has been possible to achieve a bigger awareness and creation of better conditions for those businesses. Therefore, it's worth of mentioning that microfinance institutions are a great help and they are a very important source for these businesses.

\section{SURVEYS}

Bellow we presented some data obtained through the surveys with small and medium businesses in Kosovo. These surveys were conducted in order to have a review 
of how much are the businesses aware of services and opportunities which are offered by the microfinance institutions. 54 small and medium enterprises are included in the survey. These important results are presented as follows:

\section{How much infrotmation do you have for MFI'in Kosovo?}

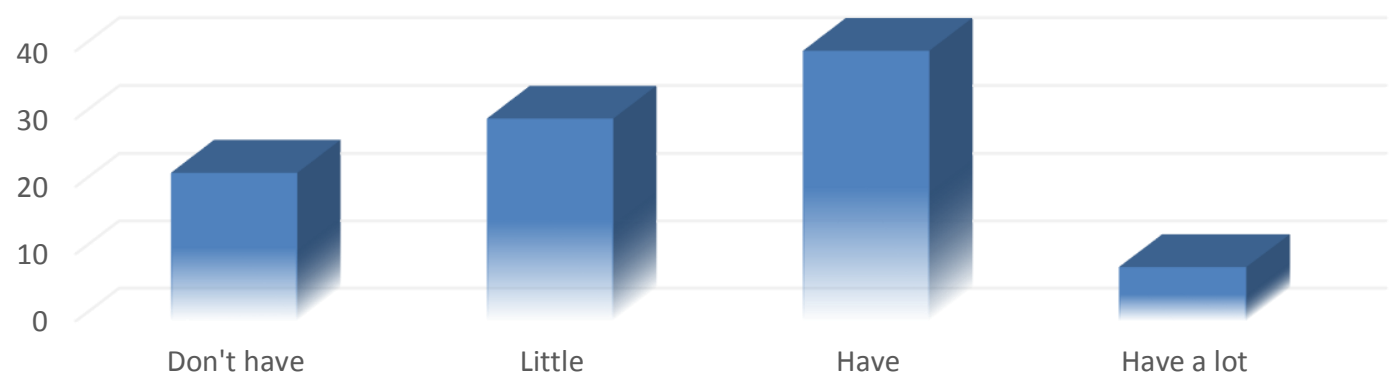

While about $50 \%$ of SME businesses have information for MFI's in Kosovo, other $30 \%$ have less and $20 \%$ of SME businesses don't have information at all for MFI's in Kosovo. The $20 \%$ of SME's who don't have knowledge at all for MFI's are urban zone business owner's as MFI's are focused in rural areas.

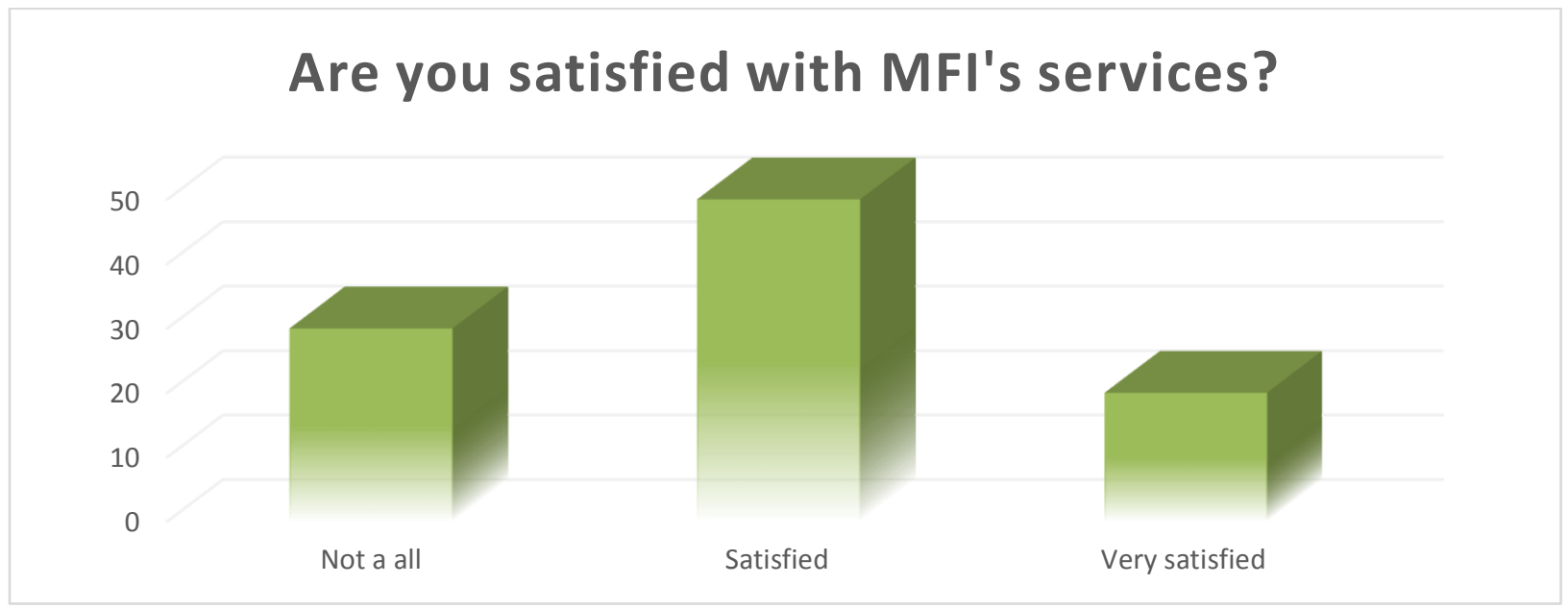

While $50 \%$ of SME businesses are satisfied and $20 \%$ very satisfied, on the other side $30 \%$ of SME businesses are not satisfied from MFI services. The 30\% dissatisfaction shown by SME businesses is because MFI's in Kosovo are not offering other credit lines except traditional loans. 


\section{Would you recommend these services to other enterprises?}

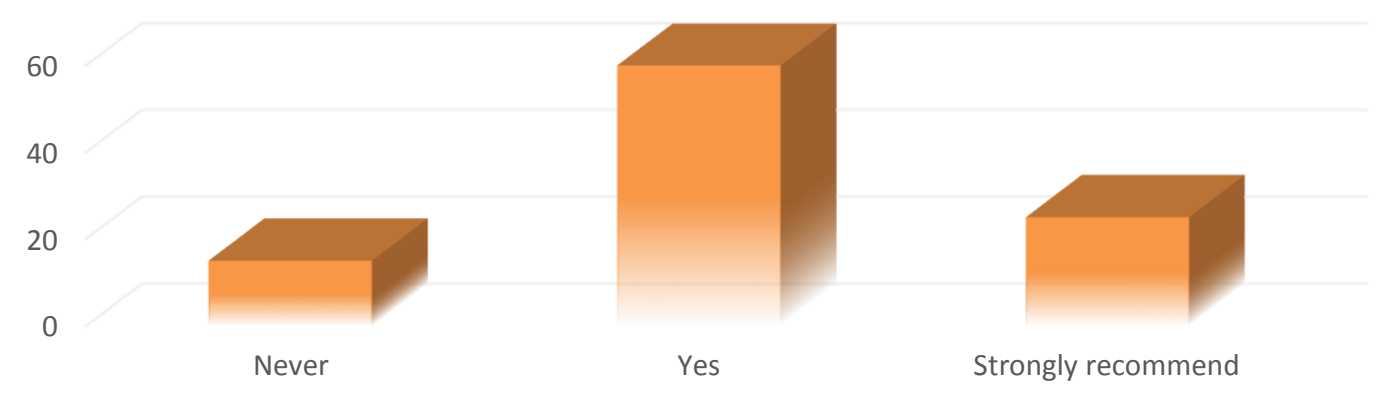

While $60 \%$ of SME businesses would recommend and about $20 \%$ strongly recommend MFI services to other enterprises, less than $20 \%$ of SME businesses wouldn't recommend this services to other enterprises.

\section{CONCLUSIONS AND RECOMMENDATIONS}

Based on these results we can conclude that microfinance institutions should do more about that, in order to raise awareness about the existence of those institutions and their services. Since, around 50\% have replied that they are satisfied with the services of microfinance institutions, still there is $15 \%$ that would not recommend these institutions services. $25 \%$ that are not at all familiar with services of microfinance institutions are a strong message that there is still more to do for the awareness of small and medium businesses.

\section{BIBLIOGRAPHY}

Finca: www.kosovofinca.org

Information Resources Management Association,2013. Small and medium enterprises: Concept, Methodologies, Tools and Applications.

KepTrust: www.keptrust.org

Kosovo International Trade Guide. http://www.itg-rks.com/sq/Getting started

KRK: www.krk.org

Mersland R. (2014). Microfinance Institutions: Financial and Social Performance. Palgrave Macmillan UK

OECD. (2016). Small and medium enterprises report. 